\title{
Comparing Labour and Total Factor Productivity Growth and Level in France, Japan, the United Kingdom and the United States over the Past Century and in Recent Years ${ }^{\S}$
}

\author{
Gilbert Cette $^{*}, 1$, Yusuf Kocoglu ${ }^{2}$ and Jacques Mairesse ${ }^{3}$ \\ ${ }^{I}$ Banque de France and Université de la Méditerranée (DEFI), France \\ ${ }^{2} L e ́ a d$, Université du Sud Toulon-Var and Centre d'études de l'emploi (CEE), France \\ ${ }^{3}$ CREST (ENSAE), UNU-MERIT (Maastricht University) and NBER, France
}

\begin{abstract}
The present study contributes to the analysis of economic growth by comparing labour ant total factor productivity (TFP) in France, Japan, the United Kingdom and the United States in the very long run (since 1890) and in the medium run (since 1980). During the past century, the United States has overtaken the United Kingdom and became the leading world economy. During the last 25 years, productivity growth has also known contrasted developments in the four countries, in particular as a result of an unequal growth of information and communication technology (ICT) investments.

The past 120 years have been characterised by: (i) rapid economic growth and large productivity gains in the four countries; (ii) a decline in productivity in the United Kingdom relative to the United States, and to a lesser extent also relative to France and Japan until the second world war (WW2), and its subsequent come-back; (iii) the remarkable catching-up of the United States by France and Japan after WW2, which was however interrupted in the case of Japan during the 1990s. The contribution of capital deepening -as it can be measured- accounts for a large share of these different performances, with an increasing share of ICT capital in the last 25 years. This contribution varies considerably over time and across the four countries, and it is always less important, except in Japan, than that of the unmeasured factors underlying TFP, such as labour skills, technical and organisational changes and knowledge spillovers.

Most recently (in 2006), before the current world crisis, hourly labour productivity levels are slightly higher in France than in the United States, and significantly lower in the United Kingdom (by roughly 10\%) and even more in Japan (30\%), while TFP levels are very close in France, the United Kingdom and the United States, but much lower (40\%) in Japan.
\end{abstract}

JEL Classification: O47, O57, E22, J24, N10.

Keywords: Productivity, growth accounting, macro-economic history.

\section{INTRODUCTION}

Productivity is a key determinant of the wealth of nations. Almost all theoretical and empirical studies that set out to explain the extremely large economic growth and living standard inequalities between countries focus on the differences in productivity levels and growth rates. These studies are very many and our study, like most others, is based on the traditional "growth accounting" framework (outlined in Box 2). Its contribution is in taking a fresh look at the productivity macroeconomic evidence for France, Japan, the United Kingdom and the United States in the very long run (since 1890) and in the more recent years (since 1980), thus covering a century during which the United States has replaced the United Kingdom as the leading world

*Address correspondence to this author at the Banque de France and Université de la Méditerranée (DEFI), France;

E-mail: gilbert.cette@banque-France.fr

${ }^{\S} \mathrm{NB}$ : The analysis presented here is the sole responsibility of the authors and not of the institutions to which they belong. economic power, and focusing on the past 25 years during which the development of modern information and communication technologies (ICT) has contributed very significantly, albeit unevenly, to productivity growth.

We have tried in this exercise to make the best use of the estimates of aggregate historical data series going back in all four countries to the end of the $19^{\text {th }}$ century for output (GDP), employment, working time and investment in physical capital (see Box 1 on Data Sources). As regards the past 25 years, we relied as much as possible on national accounts data. Many of the estimates on which our comparison is based are subject to a great deal of uncertainty and inaccuracy, not only for the most distant periods but also to a significant extent for the more recent ones. We may nevertheless hopefully consider that the orders of magnitude of these estimates, and the ensuing large differentials in productivity levels and growth rates, are fairly reliable and meaningful. One important reason to be confident is the long tradition of statistics gathering in the four countries. Another is that our comparison is limited to the economies as a whole 


\section{Box 1. Data Sources}

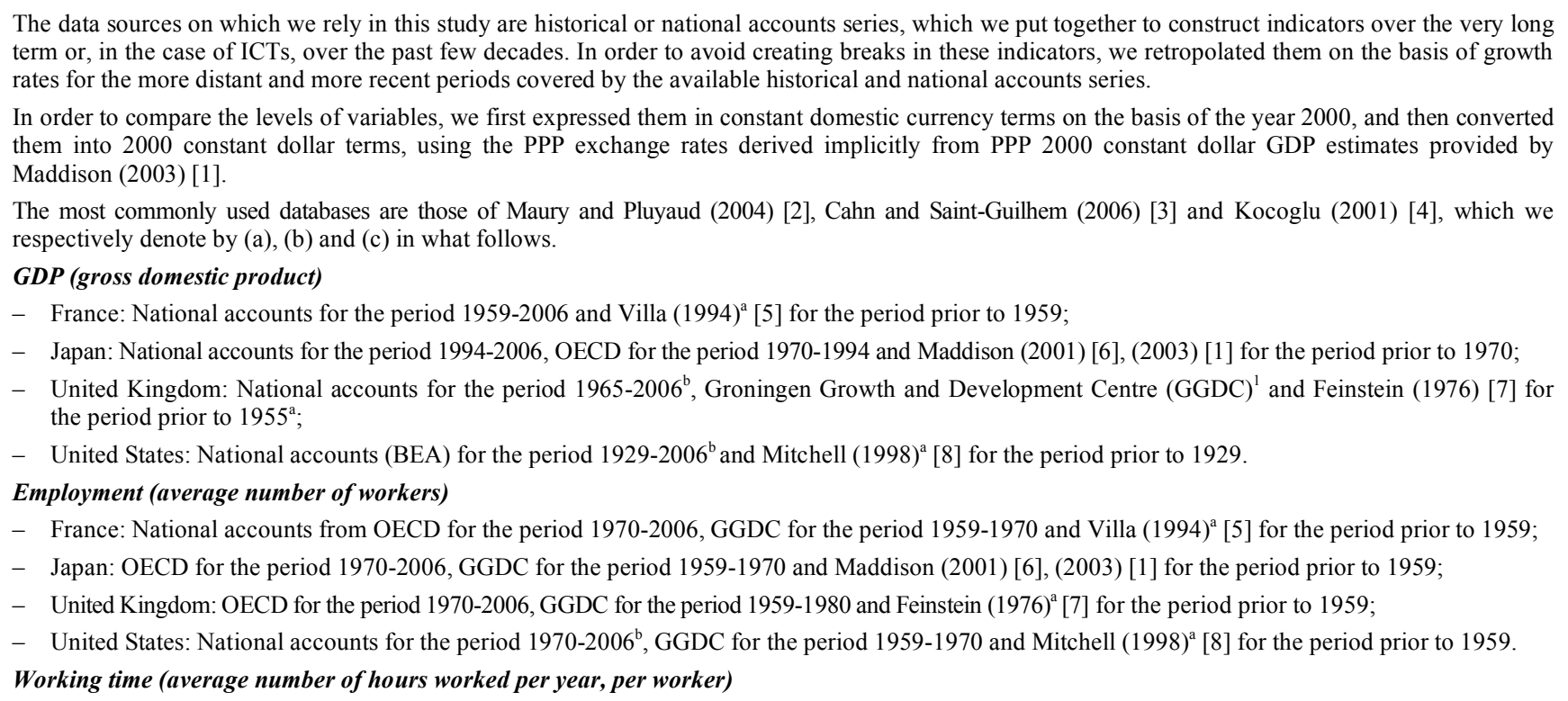

The data sources on which we rely in this study are historical or national accounts series, which we put together to construct indicators over the very long term or, in the case of ICTs, over the past few decades. In order to avoid creating breaks in these indicators, we retropolated them on the basis of growth rates for the more distant and more recent periods covered by the available historical and national accounts series.

In order to compare the levels of variables, we first expressed them in constant domestic currency terms on the basis of the year 2000 , and then converted them into 2000 constant dollar terms, using the PPP exchange rates derived implicitly from PPP 2000 constant dollar GDP estimates provided by Maddison (2003) [1].

The most commonly used databases are those of Maury and Pluyaud (2004) [2], Cahn and Saint-Guilhem (2006) [3] and Kocoglu (2001) [4], which we respectively denote by (a), (b) and (c) in what follows.

\section{GDP (gross domestic product)}

- France: National accounts for the period 1959-2006 and Villa (1994) ${ }^{\mathrm{a}}$ [5] for the period prior to 1959;

- Japan: National accounts for the period 1994-2006, OECD for the period 1970-1994 and Maddison (2001) [6], (2003) [1] for the period prior to 1970;

- United Kingdom: National accounts for the period 1965-2006 ${ }^{\mathrm{b}}$, Groningen Growth and Development Centre (GGDC) ${ }^{1}$ and Feinstein (1976) [7] for the period prior to $1955^{\text {a }}$;

- United States: National accounts (BEA) for the period 1929-2006 and Mitchell (1998) ${ }^{\mathrm{a}}$ [8] for the period prior to 1929.

Employment (average number of workers)

- France: National accounts from OECD for the period 1970-2006, GGDC for the period 1959-1970 and Villa (1994) ${ }^{\mathrm{a}}$ [5] for the period prior to 1959;

- Japan: OECD for the period 1970-2006, GGDC for the period 1959-1970 and Maddison (2001) [6], (2003) [1] for the period prior to 1959;

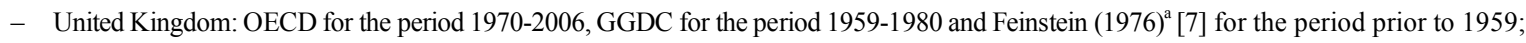

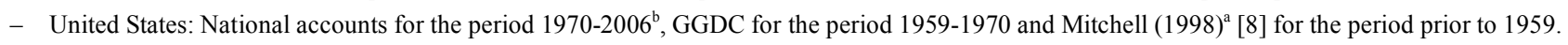

Working time (average number of hours worked per year, per worker)

For the four countries: OECD for the period 1970-2006; GGDC for the period 1950-1969; Maddison (2001) [6] for 1870, 1913 and 1950; linear interpolation for the periods 1890-1913, 1913-1950.

\section{Investment}

- France: National accounts for the period 1959-2006, Maddison (1993) [9] for the period 1935-1959, Levy-Leboyer (1978) ${ }^{\mathrm{c}}$ [10] for the period 18201935. The breakdown of total GFCF between equipment and buildings is taken from Villa (1994) [5] for the period 1820-1935;

- Japan: National accounts for the period 1980-2006 and Maddison (1993) [9] for the period prior to 1980;

- United Kingdom: National accounts for the period 1965-2006 ${ }^{\mathrm{b}}$ and Maddison (1993) [9] for the period prior to 1965;

- United States: National accounts for the period 1967-2006 ${ }^{\mathrm{b}}$ and Maddison (1993) [9] for the period prior to 1967.

\section{ICT investment}

- France: GGDC (EUKLEMS) for the period 1970-2005;

- Japan: GGDC (EUKLEMS) for the period 1970-2004;

- United Kingdom: GGDC (EUKLEMS) for the period 1970-2005;

- United States: GGDC (EUKLEMS) for the period 1970-2005 and trend from the BEA for the market economy for the period $1959-1969$.

\section{Fixed capital}

Fixed capital series are constructed on the assumption that the annual depreciation rates are: $2.5 \%$ for buildings, $10 \%$ for non-ICT equipment, $15 \%$ for communication equipment and 30\% for computer hardware and software. The coefficients used to take into account WW1 and WW2 damages in France are taken from Villa (1994) ${ }^{\mathrm{c}}$ [5]. For Japan, WW2 damages are implicitly taken into account by using the Maddison (1993) [9] growth rate for the period prior to 1946. For this country, the WW2 damage coefficients are those proposed by the Bank of Japan (1966) [11], and the Maddison depreciation assumption (1993) [9] are consistent with ours.

\section{Prices of ICT products}

The relative ICT price indexes (compared to GDP prices) for France, Japan and the United Kingdom are the same as those taken from the US national accounts (see Colecchia and Shreyer, 2001 [12] for detailed discussion about this hypothesis).

(and the fact that all four countries had reasonably stable frontiers over our study period). Moreover, given the difficulties of measuring (physical) capital, as well as uncontrolled differences in measurement methods, we thought more appropriate to simply re-estimate capital stocks and services and their contributions to growth for the four countries on the basis of the available investment series, using constant and equal capital stock depreciation rates and shares of services in GDP (see Box 1). Similarly, we chose to use the same hedonic price estimates (relative to GDP price indices) for France, Japan and the United Kingdom as those in the United States for computer hardware, software and communication equipment investments.

\footnotetext{
${ }^{1}$ The June 2007 version of the database may be downloaded at the following
} address: http://www.ggdc.net.
In short, we examine here the four countries productivity growth record both for chosen periods and sub-periods and for three notions of productivity: labour productivity per employee and per hour, and total factor productivity (TFP), measured as joint labour and physical capital productivity. We compare long-run trends in Section 2, then focus on the past 25 years evolution and on the major role played by the diffusion of ICT in Section 3.

\section{COMPARING LONG RUN PRODUCTIVITY TRENDS}

In sub-section 2.1, we first look at the average long run labour productivity and TFP trends over the entire period: 1890-2006 and comment on the 1890 and 2006 corresponding productivity levels. In sub-section 2.2 , we compare these trends and levels for the five following subperiods: from 1890 to 1913, just before WW1; from 1913 to 
Table 1. Productivity Levels and Average Growth, 1890-2006 - ppp 2000 Dollar

\begin{tabular}{|c|c|c|c|c|c|c|c|c|c|c|}
\hline & \multirow{2}{*}{\multicolumn{4}{|c|}{$\begin{array}{c}\text { Annual Average Growth Rates, as a \%, } \\
1890-2006\end{array}$}} & \multicolumn{6}{|c|}{ Levels, as a \% of the US Level } \\
\hline & & & & & \multicolumn{3}{|c|}{1890} & \multicolumn{3}{|c|}{2006} \\
\hline & France & Japan & $\begin{array}{c}\text { United } \\
\text { Kingdom }\end{array}$ & $\begin{array}{l}\text { United } \\
\text { States }\end{array}$ & France & Japan & $\begin{array}{c}\text { United } \\
\text { Kingdom }\end{array}$ & France & Japan & $\begin{array}{c}\text { United } \\
\text { Kingdom }\end{array}$ \\
\hline Labour productivity per employee & 2.1 & 2.8 & 1.4 & 1.8 & 64.7 & 22.2 & 129.3 & 91.0 & 72.6 & 86.4 \\
\hline Labour productivity per hour & 2.7 & 3.2 & 1.9 & 2.2 & 59.4 & 23.2 & 123.3 & 100.9 & 69.7 & 88.6 \\
\hline Total factor productivity per hour & 1.6 & 1.8 & 1.0 & 1.6 & 65.9 & 49.9 & 203.0 & 90.8 & 60.6 & 105.9 \\
\hline
\end{tabular}

Source: Authors' estimation, see Box 1 for data sources and Box 2 for details on TFP calculations.

1950 (i.e. including the years of the 1929 great depression and those of economic reconstruction and recovery after WW2 in order to smooth out the most significant effects of the conflict on production capacities and economic structures); from 1950 to 1973 , just before the first oil shock; from 1973 to 1980 , the period between the first and second oil shocks; and from 1980 to 2006, the period we will consider in more detail in section 3. In Section 2.2, we also carefully confront our productivity estimates to those of several other studies.

\section{1. ...Over the Entire Period}

From 1890 to 2006, the overall growth of labour productivity was remarkable in all four countries. The levels of productivity per employee and per hour increased by a factor of respectively 10 and 20 in France, 25 and 40 in Japan, 5 and 9 in the United Kingdom and 7 and 12 in the United States (see Table 1). The large differentials between the growth rates of employee and hourly productivity reflect the large decline in average annual working time: by roughly $50 \%$ in France (sliding from 3,110 hours in 1890 to 1,540 hours in 2006), by $45 \%$ in the United Kingdom (from 2,990 to 1,670 hours), $40 \%$ in the United States (from 2,850 to 1,710 ) and $35 \%$ in Japan (from 2,734 to 1,784 ). Over these (nearly) 120 years, Japan experienced the highest average annual growth: $2.8 \%$ per employee and $3.2 \%$ per hour, and the United Kingdom the lowest: $1.4 \%$ per employee and $1.9 \%$ per hour, while France and the United States were in an intermediate position, with France $(2.1 \%$ and $2.7 \%)$ above the United States (1.8\% and $2.2 \%)$.

Table 2. GDP Per Hour Worked, as a \% of the US Level

\begin{tabular}{|c|c|c|c|c|c|}
\hline & $\mathbf{1 8 7 0}$ & $\mathbf{1 9 1 3}$ & $\mathbf{1 9 5 0}$ & $\mathbf{1 9 7 3}$ & $\mathbf{2 0 0 3}$ \\
\hline \hline Japan & 20 & 21 & 16 & 49 & 64 \\
\hline United Kingdom & 113 & 84 & 63 & 67 & 79 \\
\hline
\end{tabular}

Scope : Economy as a whole - ppp 1990\$

Source: From Maddison (2007, Table 6.4, p. 305) [25].

In terms of productivity levels, few studies are available on a long period to allow some comparison with our results. Concerning productivity per hour, relative to the United States level, results from Maddison (2007) [13] seem, for Japan and the United Kingdom, very close to ours (Table 2 for the results from Maddison, 2007 [13], and Table 1 and Figs. (1, 2) for our results). Although Maddison (2007) [13] does not give a level comparison for TFP, his estimation of productivity per hour and of capital stock per capita relative to the United States seem roughly consistent with our estimates of relative TFP levels ${ }^{2}$.

In 1890, the level of US labour productivity, whether per employee or per hour, was about four to five times higher than in Japan, 50\% higher than in France, but 25\% lower than in the United Kingdom (see Table $\mathbf{1}$ and Figs. $(\mathbf{1}, \mathbf{2}))^{3}$. At the time, Japan and France had a much larger proportion of their labour force working in agriculture, as compared with the other two countries. In 2006, the situation is drastically different. The Japanese productivity level, though still the lowest, is about two thirds that of the United States, and the French productivity level is close to that of the United States, while the British productivity level is significantly lower (by about 10\%) than in the United States ${ }^{4}$.

Growth in total factor productivity (TFP) accounts for a major share of hourly labour productivity growth over the past 120 years in the four countries: roughly $50 \%$ to $60 \%$ in France, Japan and in the United Kingdom and $70 \%$ in the United States, while the contribution of capital deepening appears much smaller (see Table 4). Overall, it appears that the factors underlying TFP as computed, such as mainly a better educated and higher skilled labour force, technical and organisational changes, knowledge spillovers, better institutions, make a much greater contribution to observed productivity than capital deepening per se.

${ }^{2}$ See Maddison (2007, Table 6.4, p. 305) [13]. For example, the1913 United Kingdom capital stock per capita (in 1990\$) is estimated to be $23 \%$ of the US one, which is compatible with a (considerably) higher TFP level but a lower productivity level in the United Kingdom than in the United States.

${ }^{3}$ The relative productivity levels for France, Japan and the United Kingdom found in this study differ somewhat from those mentioned in Cette (2004) [17], (2007) [18]. These results do not alter the commented stylised facts. The causes of these differences are two-fold. First, the data sources are different: those used in the present study are detailed in Box 1 while in Cette (2004) [17], (2007) [18] they are Maddison (1994) [19], (2001) [6] and (2003) [1]. Second, in order to ensure the continuity of historical series, we chose to adjust them on the basis of growth rates (as indicated in Box 1).

${ }^{4}$ Bourlès and Cette (2005) [20], (2007) [21] have shown that France's strong productivity performance compared to the United States at the end of the period can partly be explained by strongly diminishing returns of shorter working hours and a lower employment rate. Adjusting for these effects the 2006 hourly labour productivity in France appears lower than in the United States by about $5 \%$. 


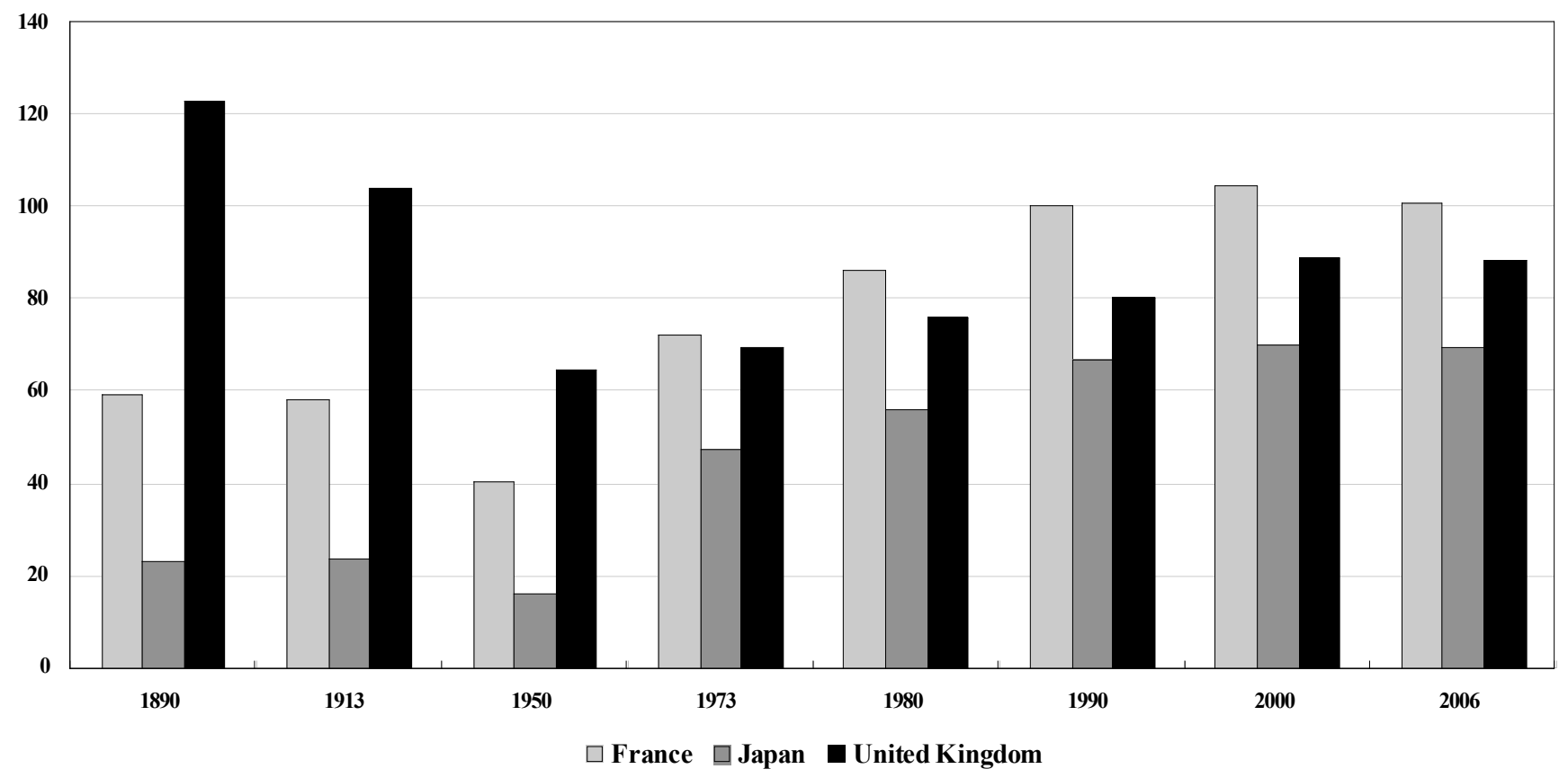

Fig. (1). Labour productivity per hour, as a \% of the US level. Scope: Economy as a whole - PPP dollar 2000.

Source: Authors' estimation, see Box 1 for data sources and Box $\mathbf{2}$ for details on TFP calculations.

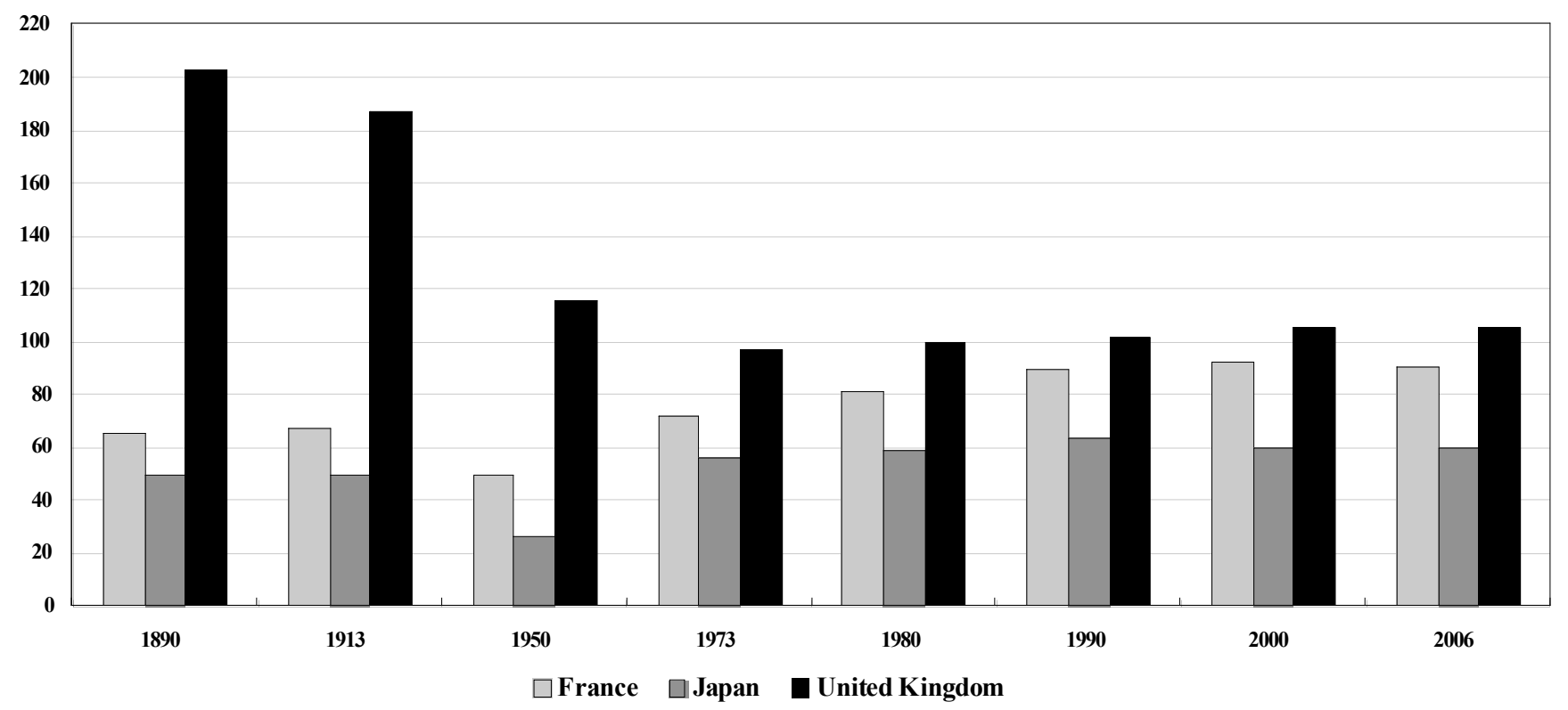

Fig. (2). Total factor productivity, as a \% of the US level. Scope : Economy as a whole - PPP dollar 2000.

Source: Authors' estimation, see Box 1 for data sources and Box 2 for details on TFP calculations.

In 1890 , the level of TFP was roughly $100 \%$ higher in the United Kingdom, but 35\% lower in France and 50\% lower in Japan than in the United States. Given that TFP growth was relatively slow in the United Kingdom and fast in France, the level of TFP in both countries was close to that in the United States in 2006. Such remarkable convergence did not occur in Japan: for TFP it ended at about $60 \%$ of the level of the United States in the early 1970s, and for hourly labour productivity it came to a halt in the early 1990s. To a significant extent, this can probably be attributed to persistent differences in industry composition. In Japan, as evidenced in Table 3, low productivity activities, such as agriculture, construction, trade and catering account for a larger share of the economy than in the other three countries.

\section{2. ...By Sub-Periods}

Our estimates of employee and hourly productivity growth and of the contributions of capital deepening and TFP are given by sub-periods in Table 4, and shown in the corresponding Fig. (3). 


\section{Box 2. The Breakdown of the Effects of TFP and Capital Deepening and the Growth Accounting Approach ${ }^{5}$}

Solow (1956 [14], 1957 [15]) was one of the first to put forward the breakdown of the effects of TFP and capital deepening on GDP and the growth accounting approach. The following equations concern the breakdown in level and growth rate terms of GDP and productivity, the commentary first covers the breakdown of growth. We assume that the production possibilities may be represented using a total production function with a total factor productivity TFP variable (or autonomous technical progress). Production (or output $\mathrm{Y}$ ) can be written as:

$\mathrm{Y}=\mathrm{TFP} . \mathrm{F}\left(\mathrm{K}_{\mathrm{j}}, \mathrm{L}_{\mathrm{i}}\right)$

where $K_{j}$ and $L_{i}$ represent respectively the volume of $j$-type capital and i-type labour (or inputs). Assuming that the production function is a CobbDouglas production function in linear log form and labour is homogeneous (which is the case in the present study), we obtain the following relation:

$y=t f p+\sum_{j} \alpha_{j} \cdot k_{j}+\beta .1$ first difference: $\Delta y=\Delta t f p+\sum_{j} \alpha_{j} \cdot \Delta k_{j}+\beta . \Delta l$

where $\mathrm{y}, \mathrm{k}_{\mathrm{j}}, 1$ and tfp represent the logs of the volume of output, j-type capital, labour and TFP, where $\Delta$ is the first difference (or annual rate of change) and where $\alpha_{j}$ and $\beta$ represent the elasticities of output with respect to the inputs $K_{j}$ and L. We assume unit (constant) returns to scale: $\sum_{j} \alpha_{j}+\beta=1$.

The growth rate of the economy can be written as the sum of the growth rate of each input weighted according to its production elasticity and the growth rate of TFP (or technical progress). Growth accounting can also be presented identically in terms of labour productivity accounting (assuming constant returns to scale), as follows:

$(\mathrm{y}-\mathrm{l})=\mathrm{tfp}+\sum_{\mathrm{j}} \alpha_{\mathrm{j}} \cdot\left(\mathrm{k}_{\mathrm{j}}-1\right)$ first difference: $(\Delta \mathrm{y}-\Delta \mathrm{l})=\Delta \mathrm{tfp}+\sum_{\mathrm{j}} \alpha_{\mathrm{j}} \cdot\left(\Delta \mathrm{k}_{\mathrm{j}}-\Delta \mathrm{l}\right)$

where $\alpha_{j}\left(k_{j}-1\right)$ represents the contribution of $j$-type capital deepening to labour productivity.

In order to apply this breakdown, it is necessary to obtain estimates of production and its factors. In macroeconomic analyses, these data are available in national accounts. The sources used in this study are detailed in Box 1. It is also necessary to measure the elasticities of production with respect to inputs. In addition to the hypothesis of constant returns to scale, it is generally admitted that production factors are remunerated at their marginal productivity (at least over the medium to long term), which means that it is possible to estimate the factor elasticities on the basis of the share of their remuneration (cost) in total income (or total cost). Given that labour costs (wages and related social security contributions) represent roughly two thirds of income, it is assumed that $\sum_{\mathrm{i}} \alpha_{\mathrm{i}}=0.3$ and therefore $\beta=0.7$.

We assume that the capital $\mathrm{K}$ used in year $\mathrm{t}$ is the stock of capital installed at the end of year $\mathrm{t}-1$.

TFP is measured as a residual: it measures the contribution to labour productivity that is not attributable to factor inputs. These types of breakdown are mainly descriptive. Although they do not provide any causal explanations, they are useful for making comparisons and explaining any differentials in productivity levels and growth rates between periods and countries.

In our study, the volume of labour $\mathrm{L}$ is written as $\mathrm{L}=\mathrm{N} . \mathrm{H}$ where $\mathrm{N}$ is the level of employment and $\mathrm{H}$ the average annual working time. The suggested breakdowns of productivity concern alternately productivity per employee or productivity per hour, and are conducted on the basis of the respective relations (where the contribution of TFP is identical):

$(\mathrm{y}-\mathrm{n})=\mathrm{tfp}+\sum_{\mathrm{j}} \alpha_{\mathrm{j}} \cdot\left(\mathrm{k}_{\mathrm{j}}-\mathrm{n}\right)+\left(1-\sum_{\mathrm{j}} \alpha_{\mathrm{j}}\right) \cdot \mathrm{h}$ first difference: $\Delta(\mathrm{y}-\mathrm{n})=\Delta \mathrm{tfp}+\sum_{\mathrm{j}} \alpha_{\mathrm{j}} \cdot \Delta\left(\mathrm{k}_{\mathrm{j}}-\mathrm{n}\right)+\left(1-\sum_{\mathrm{j}} \alpha_{\mathrm{j}}\right) \cdot \Delta \mathrm{h}$

$(\mathrm{y}-\mathrm{l})=\mathrm{tfp}+\sum_{\mathrm{j}} \alpha_{\mathrm{j}} \cdot\left(\mathrm{k}_{\mathrm{j}}-\mathrm{l}\right)$ first difference: $\Delta(\mathrm{y}-\mathrm{l})=\Delta \mathrm{pgf}+\sum_{\mathrm{j}} \alpha_{\mathrm{j}} \cdot \Delta\left(\mathrm{k}_{\mathrm{j}}-1\right)$

Table 1 and Fig. (2) present TFP per hour as a \% of the United States' TFP level per hour. From a Cobb-Douglas production function with constant returns to scale, we can write productivity per hour as follows:

$\mathrm{Y} / \mathrm{L}=\mathrm{TFP} . \Pi_{\mathrm{j}}\left(\mathrm{K}_{\mathrm{j}} / \mathrm{L}\right)^{\alpha \mathrm{j}}$,

Then the level of TFP is calculated by the following relation:

$$
\frac{Y / L}{\prod_{j}\left(K_{j} / L\right)^{\alpha j}}=T F P
$$

where the elasticity of capital to production is assumed to be constant over the period $\alpha=0.3$

Not many analyses provide comparable estimations for the four countries over the last century. As expected, our estimates of productivity per employee are very close to those of Maury and Pluyaud (2004) [2], since they largely rely on the real GDP and employment data they have gathered and harmonised.. They are also consistent with the results presented by Gordon (2003) [22], Cette (2004) [17], (2007) [18] and Van Ark, Frankema and Duteweerd (2004) [23] who measure labour productivity growth over different sub-periods using the real GDP and employment estimates calculated by Maddison (2001) [6].

Our estimates of labour productivity and TFP are also consistent with those of Maddison (2007) [13] who makes long-term comparisons between Japan, the United Kingdom and the United States, and considers in particular the same two sub-periods 1913-1950 and 1950-1973 (see Table 7).

As regards France, the estimates by Dubois (1985) [24], which builds on the major work of Carré, Dubois and ${ }^{5}$ For a history of growth accounting and TFP ("the residual"), see Griliches
(1996) [16] and Maddison (2007) [13].
Malinvaud (1972) [25], are in very good accordance with ours, although they cover only market activities (not the whole economy) and in spite of our simplified estimation of physical capital and of its to growth (see Table 5). For the United Kingdom and Japan, our estimates of labour productivity and TFP growth are very similar to the ones of Maddison (2007) [13] over both sub-periods 1913-1950 and 1950-1973 (see Table 6). For the United Kingdom, our estimates are also consistent with those of Crafts (2004a) [26], (2004b) [27] and (2004c) [28]. As regards the United States, Ferguson and Wascher (2004) [29] apply a comparable breakdown of hourly productivity growth as we do, but for the non-agricultural market sector and with slightly different sub-periods (see Table 7). Their results and ours are nonetheless not very different. Over the more recent sub-period 1950-1973, our estimates of labour productivity and TFP growth are also similar to the ones of Maddison (2007) [13]. However, for the more distant sub-period 19131950, our estimate of TFP growth is higher than Maddison's by about $0.7 \%$ per year, while our estimate of labour productivity differs 'only' by $0.3 \%$ (see Table 6 ). 
Table 3. Structure of Employment, as a \% of Total Employment

\begin{tabular}{|l|c|c|c|c|c|c|c|c|}
\hline \multirow{2}{*}{} & \multicolumn{2}{|c|}{ France } & \multicolumn{2}{c|}{ Japan } & \multicolumn{2}{c|}{ United Kingdom } & \multicolumn{2}{c|}{ United States } \\
\cline { 2 - 10 } & $\mathbf{1 9 7 0}$ & $\mathbf{2 0 0 4}$ & $\mathbf{1 9 7 0}$ & $\mathbf{2 0 0 4}$ & $\mathbf{1 9 7 0}$ & $\mathbf{2 0 0 4}$ & $\mathbf{1 9 7 0}$ & $\mathbf{2 0 0 4}$ \\
\hline \hline Agriculture and mining & 14.3 & 3.7 & 20.2 & 5.4 & 5.2 & 1.5 & 5.2 & 2.8 \\
\hline Manufacturing, gas and water & 25.8 & 14.4 & 26.5 & 17.7 & 33.0 & 12.3 & 23.2 & 10.9 \\
\hline Construction & 10.2 & 6.3 & 8.1 & 9.0 & 7.2 & 6.8 & 5.0 & 6.0 \\
\hline Wholesale and retail trade, restaurants and hotels & 15.5 & 17.3 & 20.9 & 25.5 & 19.0 & 23.3 & 21.6 & 23.8 \\
\hline Transport and storage and communication & 5.6 & 6.2 & 5.6 & 5.8 & 6.7 & 5.9 & 4.6 & 4.2 \\
\hline Other services & 28.7 & 52.0 & 18.8 & 36.6 & 28.9 & 50.2 & 40.5 & 52.3 \\
\hline \multicolumn{1}{|c|}{ Total } & 100.0 & 100.0 & 100.0 & 100.0 & 100.0 & 100.0 & 100.0 & 100.0 \\
\hline
\end{tabular}

Source: Base EUKLEMS.

Table 4. Average Annual Labour Productivity Growth and Contributions (In Percentage Points), in France, the United Kingdom and the United States

A - France

\begin{tabular}{|l|c|c|c|c|c|}
\hline & $\mathbf{1 8 9 0 - 1 9 1 3}$ & $\mathbf{1 9 1 3 - 1 9 5 0}$ & $\mathbf{1 9 5 0 - 1 9 7 3}$ & $\mathbf{1 9 7 3 - 1 9 8 0}$ & $\mathbf{1 9 8 0 - 2 0 0 6}$ \\
\hline \hline GDP & 1.9 & 0.9 & 5.3 & 2.9 & 2.1 \\
Productivity per employee [a] & 1.6 & 1.0 & 4.7 & 2.6 & 1.5 \\
Productivity per hour [b] & 1.9 & 1.8 & 5.2 & 3.4 & 2.2 \\
\hline Contributions to productivity per hour : & & & & \\
$\quad$ Capital intensity, per hour [c] & 0.5 & 0.3 & 1.2 & 1.6 & 0.9 \\
$\quad$ Total factor productivity [d] & 1.4 & 1.5 & 4.0 & 1.8 \\
\hline
\end{tabular}

\section{B - Japan}

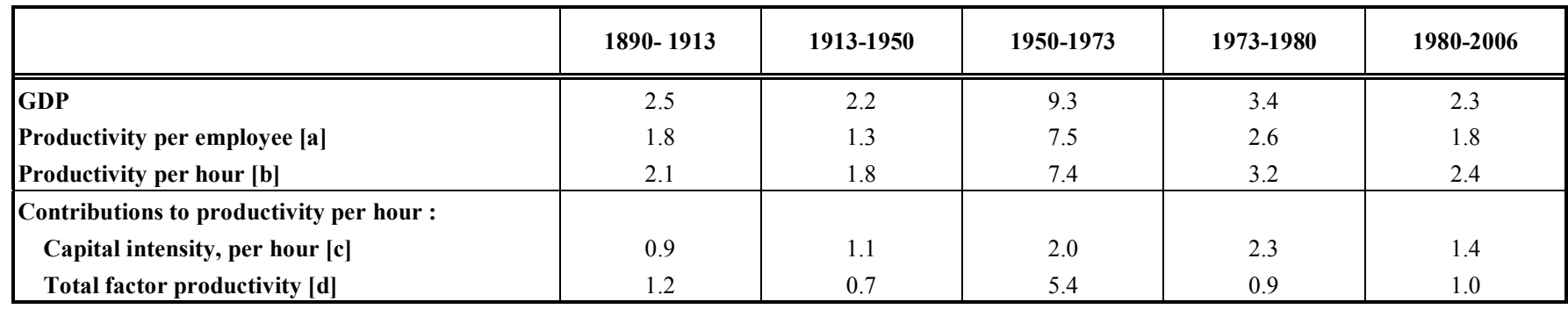

\section{C - United Kingdom}

\begin{tabular}{|l|c|c|c|c|c|}
\hline & $\mathbf{1 8 9 0 - 1 9 1 3}$ & $\mathbf{1 9 1 3 - 1 9 5 0}$ & $\mathbf{1 9 5 0 - 1 9 7 3}$ & $\mathbf{1 9 7 3 - 1 9 8 0}$ & $\mathbf{1 9 8 0 - 2 0 0 6}$ \\
\hline \hline GDP & 1.9 & 1.3 & 2.9 & 1.0 & 2.5 \\
Productivity per employee [a] & 0.9 & 0.7 & 2.5 & 0.9 & 2.0 \\
Productivity per hour [b] & 1.2 & 1.5 & 2.8 & 2.1 & \\
\hline Contributions to productivity per hour : & & & & 1.6 & \\
$\quad$ Capital intensity, per hour [c] & 0.3 & 0.5 & 1.6 & 0.5 \\
Total factor productivity [d] & 0.9 & 1.0 & 1.2 & 1.1 \\
\hline
\end{tabular}

\section{D - United States}

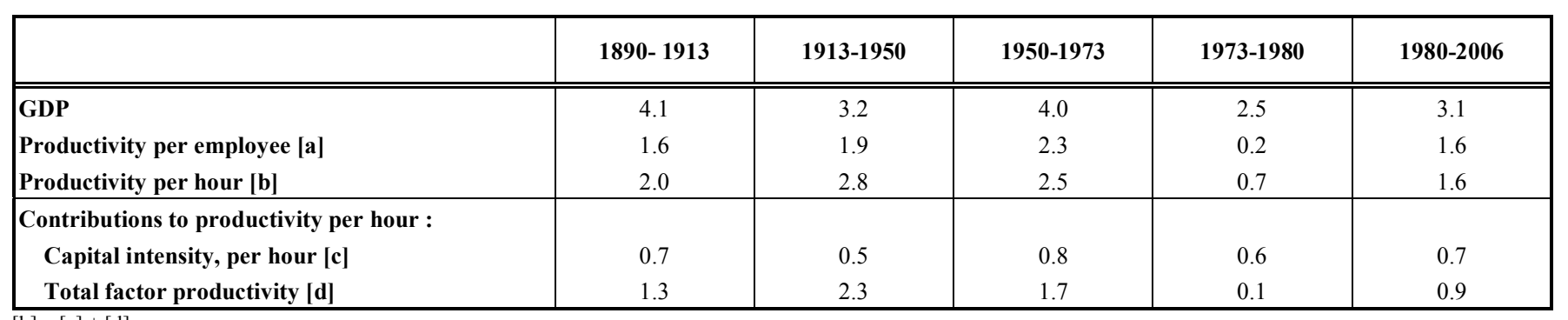

$[\mathrm{b}]=[\mathrm{c}]+[\mathrm{d}]$

Scope: Economy as a whole

Source: Authors' estimation, see Box 1 for data sources and Box $\mathbf{2}$ for details on TFP calculations. 
Table 5. Breakdown of labour productivity growth in France

\begin{tabular}{|l|c|c|c|c|c|}
\hline & $\mathbf{1 8 9 6 - 1 9 1 3}$ & $\mathbf{1 9 1 3 - 1 9 2 9}$ & $\mathbf{1 9 2 9 - 1 9 5 1}$ & $\mathbf{1 9 5 1 - 1 9 7 3}$ & $\mathbf{1 9 7 3 - 1 9 8 4}$ \\
\hline \hline Productivity per employee & 1.7 & 1.5 & 1.3 & 5.2 & 2.4 \\
Productivity per hour[b] & 2.0 & 2.5 & 1.7 & 5.6 & \\
\hline Contributions : & & & & 1.4 \\
Capital intensity, per hour [c] & 0.6 & 0.7 & 0.5 & 1.8 \\
Total factor productivity [d] & 1.4 & 1.8 & 1.2 & 4.2 & 2.0 \\
\hline
\end{tabular}

$[\mathrm{b}]=[\mathrm{c}]+[\mathrm{d}]$.

Scope: Business sector $-\%$ per year

Source: Dubois (1985) [24], from Tables 6 and 8, p. 14 and 21.

Table 6. Average Annual Labour Productivity Growth and Total Factor Productivity Growth, Per Hour (In Percentage Points)

\begin{tabular}{|c|c|c|c|c|c|c|}
\hline \multirow{2}{*}{} & \multicolumn{3}{|c|}{ Labour Productivity } & \multicolumn{3}{c|}{ Total Factor Productivity } \\
\cline { 2 - 7 } & Japan & United Kingdom & United States & Japan & United Kingdom & United States \\
\hline \hline $\mathbf{1 8 7 0 - 1 9 1 3}$ & 2.0 & 1.2 & 1.9 & -0.2 & 0.3 & 0.4 \\
\hline $\mathbf{1 9 1 3 - 1 9 5 0}$ & 1.8 & 1.7 & 2.5 & 0.2 & 0.8 & 1.6 \\
\hline $\mathbf{1 9 5 0 - 1 9 7 3}$ & 7.7 & 3.1 & 2.8 & 5.1 & 1.5 & 0.9 \\
\hline $\mathbf{1 9 7 3 - 2 0 0 3}$ & 2.6 & 2.2 & 1.7 & 0.6 & 0.7 \\
\hline
\end{tabular}

Scope: Economy as a whole

Source: Maddison (2007) [13], Table 6.5, p. 306.

Table 7. Breakdown of US Hourly Productivity Growth

\begin{tabular}{|l|c|c|c|c|c|c|}
\hline & $\mathbf{1 8 9 0 - 1 9 1 7}$ & $\mathbf{1 9 1 7 - 1 9 2 7}$ & $\mathbf{1 9 2 7 - 1 9 4 8}$ & $\mathbf{1 9 4 8 - 1 9 7 3}$ & $\mathbf{1 9 7 3 - 1 9 9 5}$ & $\mathbf{1 9 9 5 - 2 0 0 3}$ \\
\hline \hline Productivity per hour [b] & 1.5 & 3.8 & 1.8 & 2.9 & 1.4 & 3.0 \\
\hline Contributions : & & & & & & \\
\hline Capital intensity, per hour [c] & 0.7 & 1.0 & 0.1 & 1.0 & 1.0 & 1.6 \\
\hline Total factor productivity [d] & 0.8 & 2.8 & 1.7 & 1.9 & 0.4 & 1.4 \\
\hline
\end{tabular}

Scope: Non-agricultural market sector $-\%$ per year.

$[\mathrm{b}]=[\mathrm{c}]+[\mathrm{d}]$.

Source: Ferguson and Wascher (2004) [29], p. 6

Putting together the two sub-periods after the first oil shock, our results confirm the "Big Wave" analysis of productivity in the United States offered by Gordon (1999) [30], (2003) [22]. Hourly productivity in the United States and TFP accelerate after 1913, and then slows down after 1950 and again after 1973, while the contribution of capital deepening to growth remains almost unchanged. Employee productivity has a different evolution, growing fastest from 1950 to 1973, not before from 1913 to 1950. In France, Japan and the United Kingdom, we also observe such a "Big Wave". It is, however, shifted forward, with both hourly and employee productivity growing faster during the years 19501973 than in the previous years 1913-1950. It appears more pronounced in Japan than in France, and in France than in the United Kingdom. These differences between the three countries and with the United States can be attributed to several factors, among which the later diffusion of electric energy, the later improvement in the average education and skill level of the workforce (See van Ark, Frankema and Duteweerd, 2004) [23] and a higher degree of protectionism (see Gordon, 2003, for a review of the literature) [22]. As in the United States, TFP is the main determinant of employee and hourly productivity growth in France, Japan and the United Kingdom, with capital deepening nonetheless contributing importantly. It is worth pointing out that the contribution of capital is always greater in Japan than in the other three countries, reflecting a higher capital accumulation rate.

Looking more precisely, we see beyond these broad similarities substantial across the four countries depending on the sub-periods considered. From 1890 to 1913, France, Japan and the United States recorded similar annual growth rates of productivity per employee (roughly $1.7 \%$ ) and per hour (roughly 2\%). Annual productivity growth was the lowest in the United Kingdom, mainly on account of a smaller TFP contribution and, to a lesser extent, a smaller rise in capital deepening. In the four countries, the shares of the contributions of capital deepening and TFP to productivity growth are very similar (respectively $1 / 4$ to $1 / 2$ 


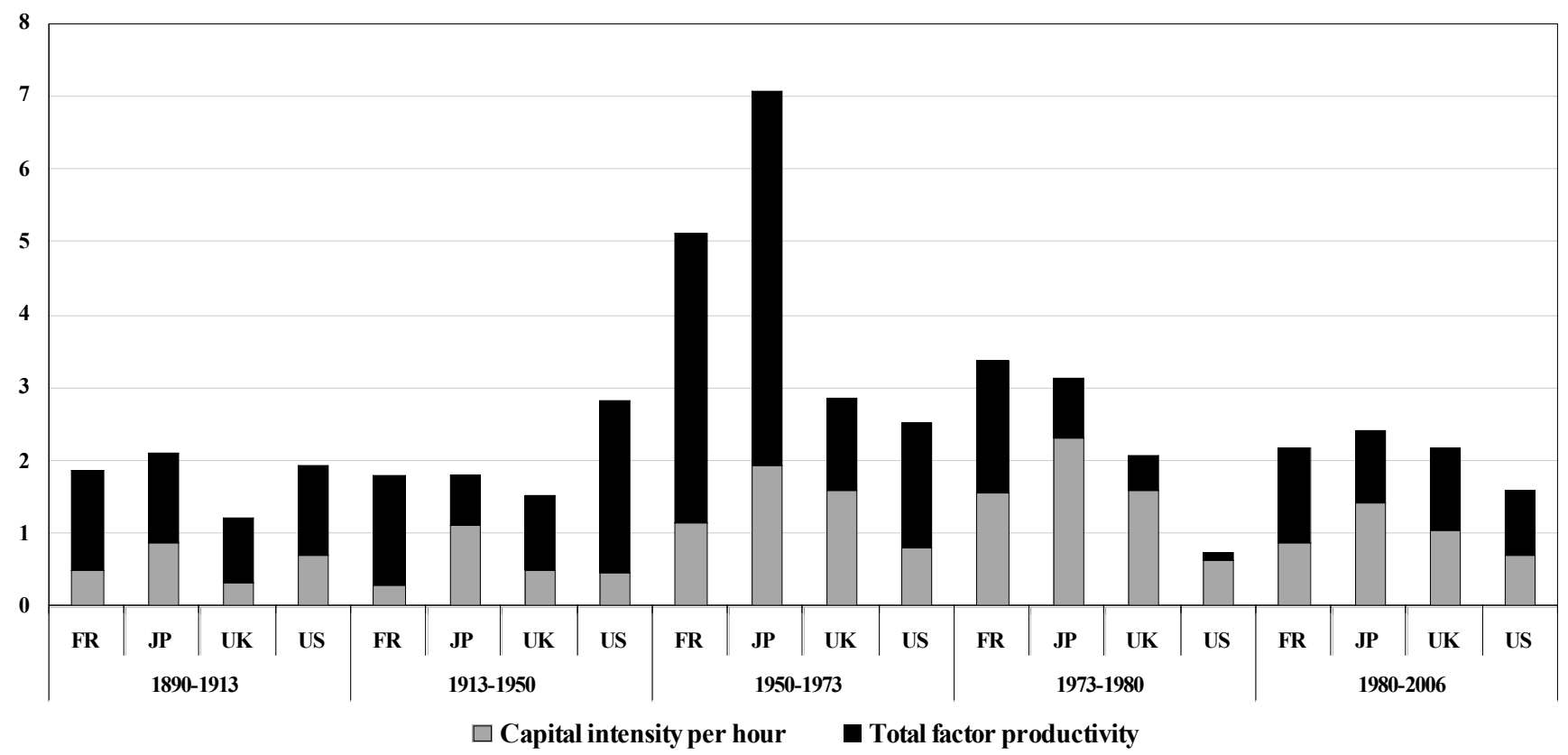

Fig. (3). Average annual hourly labour productivity growth (in \%) and contributions in France, Japan, the United Kingdom and the United States -1890-2006- in percentage points. Scope: Economy as a whole.

Source: Authors' estimation, see Box 1 for data sources and Box 2 for details on TFP calculations.

and $1 / 2$ to $3 / 4$ ). Compared with that of the United States, the level of hourly productivity in France and Japan thus remained unchanged at respectively roughly $45-50 \%$ and 20 $25 \%$, while that in the United Kingdom dropped from around $125 \%$ to $105 \%$.

From 1913 to 1950, annual productivity growth (per employee and per hour) was much faster in the United States (where it stood at $1.9 \%$ and $2.8 \%$ respectively) than in France $(1.0 \%$ and $1.8 \%)$ and Japan $(1.3 \%$ and $1.8 \%)$ and, in particular, the United Kingdom (0.7\% and $1.5 \%)$. Except for Japan, these discrepancies can be attributed to different TFP contributions, as the contribution of capital deepening was about the same in all three countries and almost equal to that in the previous sub-period. In Japan, the contribution of capital deepening is very high during this sub-period (roughly $70 \%$ of hourly productivity growth). Consequently, compared to that in the United States, the relative level of hourly productivity dropped in 1950 by a few points for France and Japan to respectively roughly $40 \%$ and $20 \%$, and much more for the United Kingdom to $65 \%$.

From 1950 to 1973, annual productivity growth (per employee and per hour) was very strong in Japan $(7.5 \%$ and $7.4 \%$ respectively) and in France $(4.7 \%$ and $5.2 \%$ respectively), stable in the United Kingdom (2.5\% and 2.8\%) and slower in the United States $(2.3 \%$ and $2.5 \%)$. Productivity growth in Japan and the United States can be attributed mainly to TFP growth (for more than 70\%), while the rise in capital deepening accounts for about $50 \%$ of productivity growth in France and in the United Kingdom. In the United States, the contribution of capital deepening remains quite unchanged. France and Japan thus appear to be rapidly catching up with the other two countries, more via TFP growth than by the spread of more capital intensive production techniques for Japan and the contrary for France. The productivity gap between the four countries can also be explained by changes in the countries' economic structure. For example, it is mainly during this period that the share of agriculture in French GDP declined significantly, more in line with that in the United Kingdom and the United States. Card and Freeman (2002) [31] estimated that between 1960 and 1979 , the impact on labour productivity of a change in the weight of employment in the agricultural sector amounted to roughly 0.5 point each year in France, against 0.1 point in the United Kingdom and the United States. Consequently, relative to that in the United States, the level of hourly productivity in France and Japan improved markedly to stand at respectively $70 \%$ and $50 \%$ in 1973 ; the level in France was identical to that recorded in the United Kingdom, which had experienced a slower productivity growth.

During the short period between the two oil shocks (1973-1980), annual productivity growth (per employee and per hour) slowed significantly in the four countries. It was the highest in France (2.6\% and 3.4\% respectively) and in Japan (2.6\% and 3.2\%), intermediate in the United Kingdom $(0.9 \%$ and $2.1 \%)$ and very low in the United States $(0.2 \%$ and $0.7 \%$ ). Bourlès and Cette (2007) [21] have made the case that the slowdown in US productivity growth over this sub-period can largely (for two thirds) be accounted by a rise in the employment rate and a smaller decline in working hours, with strong diminishing returns in both variables. In Japan and the United Kingdom, the slowdown in productivity growth is also mainly linked to the slowdown in TFP growth, the contribution of capital deepening being almost unchanged for the United Kingdom or even higher in Japan compared with the previous sub-period. In France, the 
slowdown in productivity growth is mainly linked to the slowdown in capital deepening. In Japan, given that the contribution of capital deepening increased, the slowdown in productivity was less pronounced than the slowdown in TFP. Consequently, relative to that in the United States, the level of hourly productivity in France improved markedly to stand at around $85 \%$ in 1980 and more slightly in Japan and the United Kingdom to roughly $55 \%$ and $75 \%$.

Finally, during the last sub-period 1980-2006, per employee, hourly productivity and TFP slowed down again in France and Japan but accelerated in the United States. In the United Kingdom, per employee productivity also accelerated, with hourly productivity continuing to increase at the same rate. As a result, the productivity performance of the four countries depends much on the indicator considered. Productivity per employee increased fastest in the United Kingdom (2.0\%), followed by Japan (1.8\%), the United States $(1.6 \%)$ and France $(1.5 \%)$, while hourly productivity increased most rapidly in Japan (2.4\%), followed by France and the United Kingdom (2.2\%) and the United States $(1.6 \%)$. The slowdown in productivity can be attributed to the slowdown in both capital deepening and TFP growth in France, and to capital deepening only in Japan. In the United Kingdom, TFP accelerated markedly (from $0.1 \%$ to $0.9 \%$ ) while the contribution of capital deepening remained about the same (about $0.7 \%$ ). France continued to experience the highest TFP growth, in spite of very significant slowdown (from $1.8 \%$ to $1.3 \%$ ). Consequently, the level of hourly productivity relative to that in the United States increased markedly in France to become equivalent to the one in the United States, and to a lesser extent in Japan and in the United Kingdom to roughly $70 \%$ and $90 \%$.

\section{LOOKING MORE CLOSELY AT PRODUCTIVITY GROWTH IN THE 1980-2006 PERIOD}

In sub-section 3.1 we first focus on the changes in productivity growth over the five to ten years sub-periods 1980-1990, 1990-1995, 1995-2000 and 2000-2006, then in sub-section 3.2 we consider and comment on the specific contribution to growth of the rapid and pervasive diffusion of information and communication technologies (ICT) in these sub-periods.

\subsection{Changes in Productivity Growth}

Our estimates of employee and hourly productivity growth and the contributions of non-ICT and ICT capital deepening and TFP are presented by sub-periods in Table $\mathbf{8}$, and in the corresponding Fig. (4) (in a comparable format as Table 4 and Fig. (3) in the previous Section).

During sub-period 1980-1990, employee productivity growth was the highest in Japan with an average rate of $2.7 \%$ per year, followed by France and the United Kingdom with a rate close to $2 \%$, and it was the lowest in the United States with a rate of $1.4 \%$ (still, a much higher average rate than the $0.2 \%$ recorded in the previous sub-period 1973-1980). Hourly productivity growth was much faster in both Japan and France (close to 3\%) than in the United Kingdom $(2.0 \%)$ and the United States $(1.4 \%)$. The growth differential in hourly productivity between Japan and France on the one hand and the
United Kingdom and the United States on the other can be accounted for by a higher TFP $(1.6 \%$ and $1.8 \%$ as against $1.0 \%$ and $0.8 \%$ ), as well as a greater contribution of capital deepening (1.6\% and $1.2 \%$ as against $0.9 \%$ and $0.6 \%$ ).

Over the sub-period 1990-1995, productivity growth differed widely across countries. In the United States, it was slightly slower than in the previous sub-period 1980-1990, corresponding to a slower TFP growth. In the United Kingdom, employee and hourly productivity growth increased sharply (by $0.7 \%$ and $0.8 \%$ respectively). A large share of this acceleration ( 0.6 point) is due to a higher contribution of capital deepening. In France, employee and hourly productivity growth slowed considerably, both by about 1 point. This slowdown reflects almost entirely that in TFP growth (which declined by $1.0 \%$ ), and probably corresponds to a strong cyclical component given the decrease in GDP growth. The French characteristic of strong TFP growth as compared to the United Kingdom and the United States thus disappeared from the early 1990s. In Japan, employee and hourly productivity growth also slowed down considerably, by 1.8 point and 0.7 point respectively. As in France, this slowdown appears to be mostly related to a corresponding slowdown in TFP growth.

The sub-period 1995-2000 is characterised by a significant rise in GDP growth in France, the United Kingdom and the United States (by roughly 1.5 point per year) but not in Japan where GDP growth slowed even further than previously (by 0.5 point). Like in the first half of the $1990 \mathrm{~s}$, productivity growth has known contrasted developments in the four countries. In the United Kingdom, per hour and hourly productivity growth slowed down by approximately 0.5 point per year, which can be attributed to a lower contribution of non-ICT capital deepening and of TFP. In France, it remained stable, the acceleration in TFP being offset by a slowdown in non-ICT capital deepening (by $0.6 \%$ ). This slowdown could partly result from the implementation of policies designed to enhance the labour intensity of growth, in particular reducing working time and cutting social contributions targeted at low skilled workers (see Cette, 2004) [17]. In the United States, productivity growth gained approximately $1 \%$ due to faster TFP growth. According to Gordon (2005) [32], the fact that productivity accelerates in the United States but slows in Europe can be attributed to several factors, among which a predominance of ICT producing industries, public policies that promote entrepreneurship and a better synergy between public research, private research and the financing of innovation. Finally in Japan, TFP growth remained stable and the slowdown in productivity is entirely due to a slowdown in non-ICT capital deepening.

Last, the sub-period 2000-2006 is characterised by a slowdown in productivity (about $0.4 \%$ ) in France and the United-Kingdom and a small acceleration in productivity in the two other countries (by 0.2 point). This is mainly accounted by a smaller contribution of ICT capital deepening in the United Kingdom, of TFP in France, a higher contribution of capital deepening in the United States and of TFP in Japan. 
Table 8. Average Annual Labour Productivity Growth and Contributions (In Percentage Points) in France, the United Kingdom and the United States

\section{A - France}

\begin{tabular}{|l|c|c|c|c|c|}
\hline & $\mathbf{1 9 8 0 - 2 0 0 6}$ & $\mathbf{1 9 8 0 - 1 9 9 0}$ & $\mathbf{1 9 9 0 - 1 9 9 5}$ & $\mathbf{1 9 9 5 - 2 0 0 0}$ & $\mathbf{2 0 0 0 - 2 0 0 6}$ \\
\hline \hline GDP & 2.1 & 2.4 & 1.2 & 2.8 & 1.7 \\
Productivity per employee [a] & 1.5 & 2.1 & 1.2 & 1.2 & 1.9 \\
Productivity per hour [b] & 2.2 & 2.9 & 1.8 & 0.5 & 0.2 \\
\hline Capital intensity per hour [c] & 0.9 & 1.2 & 0.8 & 0.7 \\
$\quad$ Non-ICT capital intensity per hour & 0.6 & 0.9 & 0.2 & 0.3 & 0.3 \\
ICT capital intensity per hour & 0.3 & 0.3 & 0.8 & 0.9 \\
TFP [d] & 1.3 & 1.7 & & \\
\hline
\end{tabular}

B - Japan

\begin{tabular}{|l|c|c|c|c|c|}
\hline & $\mathbf{1 9 8 0 - 2 0 0 6}$ & $\mathbf{1 9 8 0 - 1 9 9 0}$ & $\mathbf{1 9 9 0 - 1 9 9 5}$ & $\mathbf{1 9 9 5 - 2 0 0 0}$ & $\mathbf{2 0 0 0 - 2 0 0 6}$ \\
\hline \hline GDP & 2.3 & 3.9 & 1.5 & 1.0 & 1.5 \\
Productivity per employee [a] & 1.8 & 2.7 & 0.9 & 1.0 & 1.7 \\
Productivity per hour [b] & 2.4 & 3.1 & 2.4 & 1.9 & 2.0 \\
\hline Capital intensity per hour [c] & 1.4 & 1.6 & 1.5 & 0.9 & 0.8 \\
$\quad$ Non-ICT capital intensity per hour & 1.0 & 0.3 & 0.4 & 0.6 & 0.3 \\
\multicolumn{1}{|l|}{ ICT capital intensity per hour } & 0.4 & 0.3 & 0.5 & 0.2 & 1.2 \\
TFP [d] & 1.0 & 1.5 & & \\
\hline
\end{tabular}

\section{C - United-Kingdom}

\begin{tabular}{|c|c|c|c|c|c|}
\hline & $1980-2006$ & 1980-1990 & 1990-1995 & 1995-2000 & 2000-2006 \\
\hline GDP & 2.5 & 2.6 & 1.7 & 3.2 & 2.5 \\
\hline Productivity per employee [a] & 2.0 & 1.9 & 2.5 & 1.9 & 1.6 \\
\hline Productivity per hour [b] & 2.2 & 2.0 & 2.8 & 2.3 & 2.0 \\
\hline Capital intensity per hour [c] & 1.1 & 1.0 & 1.5 & 1.1 & 0.9 \\
\hline Non-ICT capital intensity per hour & 0.6 & 0.6 & 1.1 & 0.4 & 0.5 \\
\hline ICT capital intensity per hour & 0.5 & 0.4 & 0.4 & 0.7 & 0.4 \\
\hline TFP [d] & 1.1 & 1.0 & 1.3 & 1.2 & 1.1 \\
\hline
\end{tabular}

\section{D - United States}

\begin{tabular}{|c|c|c|c|c|c|}
\hline & $1980-2006$ & $1980-1990$ & 1990-1995 & 1995-2000 & 2000-2006 \\
\hline GDP & 3.1 & 3.3 & 2.5 & 4.1 & 2.4 \\
\hline Productivity per employee [a] & 1.6 & 1.4 & 1.2 & 2.0 & 1.9 \\
\hline Productivity per hour [b] & 1.6 & 1.4 & 1.0 & 2.0 & 2.2 \\
\hline Capital intensity per hour $[\mathrm{c}]$ & 0.7 & 0.6 & 0.5 & 0.8 & 1.0 \\
\hline Non-ICT capital intensity per hour & 0.3 & 0.3 & 0.2 & 0.1 & 0.6 \\
\hline ICT capital intensity per hour & 0.4 & 0.3 & 0.3 & 0.7 & 0.4 \\
\hline TFP $[\mathrm{d}]$ & 0.9 & 0.8 & 0.5 & 1.2 & 1.2 \\
\hline
\end{tabular}

Scope: Economy as a whole

$[\mathrm{d}]=[\mathrm{b}]-[\mathrm{c}]$

Source: Authors' estimation, see Box 1 for data sources and Box 2 for details on TFP calculations. 


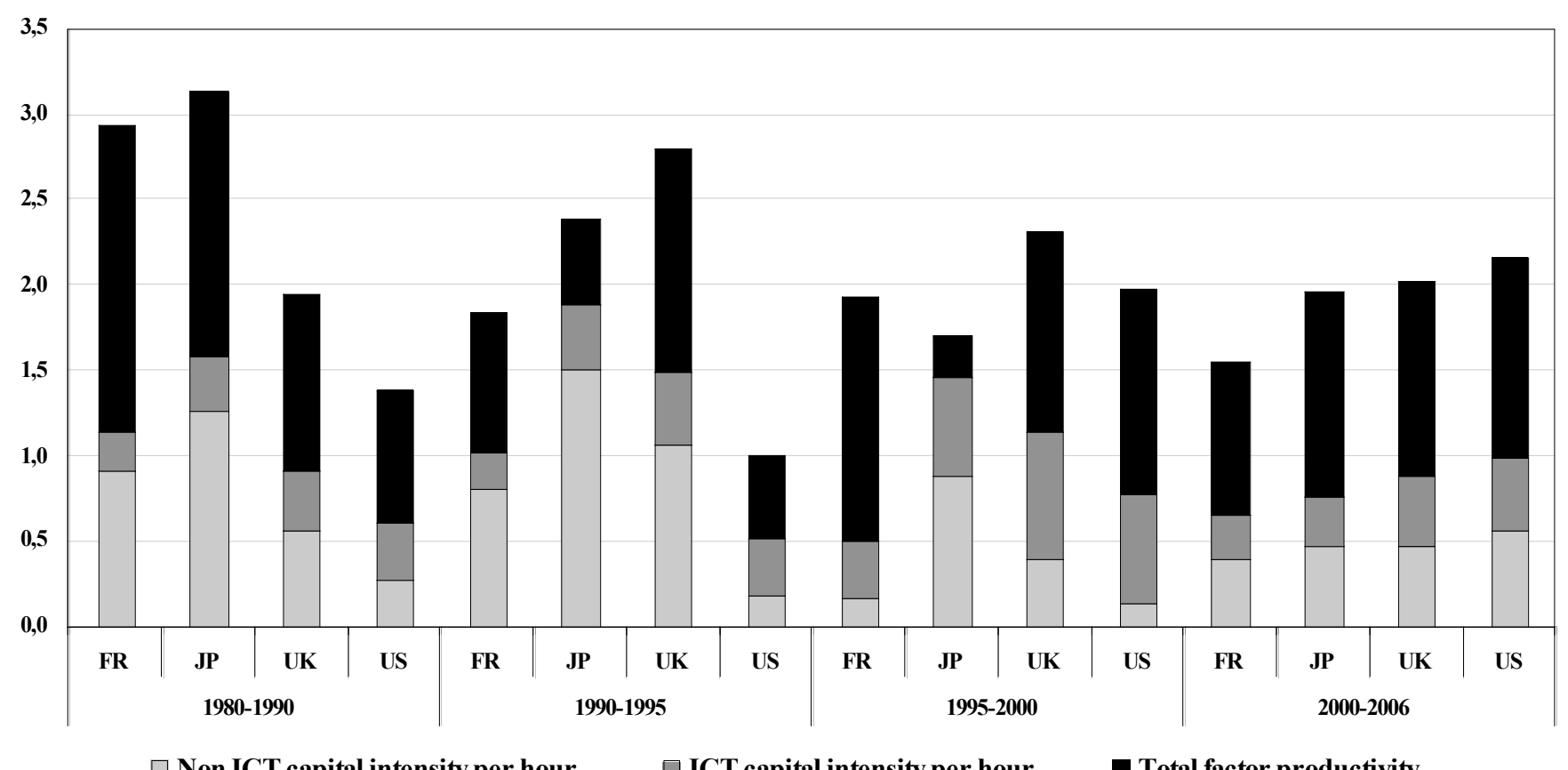

$\square$ Non ICT capital intensity per hour

$\square$ ICT capital intensity per hour

Total factor productivity

Fig. (4). Average annual hourly labour productivity growth (in \%) and contributions in France, Japan, the United Kingdom and the United States -1890-2006- in percentage points. Scope: Economy as a whole.

Source: Authors' calculation, see Box 1 and Box 2.

To conclude, productivity per employee and per hour figures show that growth was higher in the United States over the period 1995-2006 than in three others countries (only over the period 2000-2006 for the United Kingdom for productivity per hour) therefore the catching-up process stopped. We can explain this result by a higher acceleration compared to previous period in capital intensity (ICT and non-ICT) and in TFP (mainly due to ICT producer industries, see below). Therefore the success of the United States' productivity growth relative to the three other countries over the period 1995-2006 is not only due to ICT diffusion, even though it is an important element.

\subsection{The Contribution of ICTs to Productivity}

Very many studies (see for example Cette, Mairesse and Kocoglu, $2002[33,34]$ and $2005[35,36]$ for a review of the literature) have tried to assess the contribution of ICTs to GDP and productivity growth, many of them relying on macroeconomic evidence and on the growth accounting framework. Most, if not all, of these studies conclude that ICTs have had a positive and significant impact over the past two decades, via two main channels:

- $\quad$ Substitution effects linked to the accumulation of ICT capital (capital deepening), which itself results from the continuous and rapid improvements in the productive performances of ICT investments, leading to a sharp fall in the price of ICT relative to other capital goods and labour. To take the most striking case, in the United States over the 1980-2004 period the price of computer hardware has decreased at an average yearly rate of $15 \%$, while the GDP price deflator increased at an average yearly rate of $3 \%$.
- TFP gains largely driven by rapid technological progress in the different ICT-producing industries and to the productivity gains in the ICT-using industries via spillover effects.

As stressed in Cette, Mairesse and Kocoglu (2000) [37], (2002) $[33,34]$, the relative importance attached to these two effects in growth accounting analyses depends to a great extent on the methodological choices and practises of statisticians and national accountants in measuring prices and dividing the ICT investment series in terms of nominal values in the corresponding series in terms of "volumes" (say at the prices of the preceding year) and of price changes. Schematically, the more the estimation of price changes takes into account the improvements in ICT performances (through substantially upgraded products or new products), by relying in particular on hedonic methods, the larger is the contribution of capital deepening to productivity gains and the lower that of TFP, and conversely.

In what follows we first briefly comment on the estimates of the ICT investment ratios to GDP in the four countries, then on the changes in ICT prices. We finally focus on the comparison of our estimates of the ICT capital deepening contribution to productivity growth across the four countries and with other studies.

\section{a) ICT Investment Ratios to GDP}

Measuring ICT investment in nominal terms already raises a number of difficulties. Putting aside the problem of the availability and reliability of the long enough series which are needed to estimate capital stocks and services by implementing the (misleadingly called) permanent inventory method, a major difficulty is the breakdown between 
investment and intermediate consumption of total ICT expenditures, another one is the evaluation of expenditures on custom software and the adaptation of prepackaged software.. The solutions adopted by national accountants have differed between countries as well as over time. For example, following the OECD recommendations on the international harmonisation of the methods for measuring software investment (i.e. "Gross Formation of Fixed Capital"), INSEE, the French National Institute for Statistics and Economic Studies, has changed in the current 2000 based French national accounts its methods for breaking down software expenditures between intermediate consumption and investment on the one hand, and for measuring custom software expenditures on the other. As a result, the amount of software investment in 1999 rose from 11 billions Euros in the previous 1995 based national accounts to 21 billions euros in the current 2000 base, that is a $90 \%$ increase. In the United Kingdom, Chesson and Chamberlin (2006) [38] have shown that the methodological change in the measurement of software investment, particularly own account software, has led to a rise in the ratio of total software investment to GDP from $0.8 \%$ to $1.8 \%$ in 1999. These measurement difficulties also concern, but to a lesser extent, the estimation of ICT hardware investment. The estimates presented here are based on the most recent available statistics, and thus show differences compared to oldest comparable previous studies ${ }^{6}$.

The following observations can be made on Fig. (5) showing the ICT investment ratios in the four countries:

- $\quad$ In 1980, ICT investment in the United States accounted for $2 \%$ of GDP against only $1.2 \%$ in France and the United Kingdom and 1.4\% in Japan. In 2005, the share of ICT investment to GDP increased by a factor of two in the four countries;

- $\quad$ The ICT investment ratio to GDP has overall very roughly similar evolutions in the four countries. It accelerated from 1980 to 1985 and from 1995 to 2000, and remained stable, or even declined, from 1985 to 1994, and dropped from 2001 to 2005;

- $\quad$ The burst of the Internet bubble in 2000-2001 led to a substantial fall in the ICT investment ratio in the four countries. In the United Kingdom and the United States particularly the ICT investment ratio fell from $4.9 \%$ to $3.6 \%$ between 2000 and 2005 . Such fall in ICT investment appears as a correction to its very rapid increase at the end of the 1990s, which had been partly fuelled by the financial market euphoria and the fears surrounding the Y2K bug.

\section{b) Changes in ICT Prices}

As already mentioned, perhaps the major difficulty -and consequently uncertainties - in measuring the contribution of ICT capital deepening to growth lies in the measurement of

\footnotetext{
${ }^{6}$ Between 1980 and 2005, computer hardware prices in the United States posted an average annual decline of $15 \%$, compared with roughly $1 \%$ for software and communication equipment.
}

changes in the prices of ICT products, which have known very rapid quality improvements. Price statisticians and national accountants are gradually adopting hedonic methods to adjust prices for such quality improvements. However, there are substantial differences in the way in which countries apply these methods (see Cette, Mairesse and Kocoglu, 2000 [37], 2002 [33, 34]). In order to prevent that such differences affect our comparison, and considering that ICT products with basically comparable characteristics are produced or imported, and hence invested in the four countries, we chose to rely only on the US national accounts price indices for ICT products. Precisely, we have assumed that the quality adjusted prices for the three ICT products categories that can be distinguished in the national accounts (i.e., computer hardware, software and communication equipment) are the same in France, Japan and the United Kingdom than in the United States, relative to the national GDP overall price index. This method, proposed by Colecchia and Shreyer (2001) [12], seems realistic enough for developed countries and better than relying on the national accounts using ICT products price statistics which are not yet based on harmonised methods for quality adjustment.

Table 9 gives the overall ICT price average yearly growth rates by sub-period in the four countries calculated by weighting the price growth rates for computer hardware, software and communication equipment. The differences between countries arise from (i) differences in the GDP price growth rates and (ii) the composition of ICT investments in computer hardware, software and communication equipment. Computer hardware experienced the largest price fall relative to other ICT products ${ }^{7}$. Over the 1980-2005 period, the average annual decline in ICT prices was of the same magnitude in the United Kingdom and the United States (roughly 5\%). In Japan, ICT prices decreased somewhat faster (by 5.7\% per year) due to the slower growth of GDP price $(0.7 \%$ compared to $3 \%)$ and due to a larger share of computer hardware ${ }^{8}$.

In France, they decreased less rapidly (by $4 \%$ per year) because of smaller share of computer hardware and a faster growth of GDP price. The 1995-2000 period is that of most pronounced decease in ICT prices in the four countries, ranging from $6.7 \%$ per year in France to $9.5 \%$ per year in Japan.

\section{c) The Contribution of ICTs to Productivity Growth}

The contribution of ICTs to labour productivity growth is shown in Table 8 and Fig. (4). The main findings are the following:

- $\quad$ Over the entire 1980-2006 period, the contribution of ICT capital to productivity growth per hour is greater than that of non-ICT capital in the United States and lower in the other three countries;

\footnotetext{
${ }^{7}$ Between 1980 and 2005, computer hardware prices in the United States has decreased at an average annual rate of $15 \%$, compared with roughly $1 \%$ for both software and communication equipment.

${ }^{8}$ On average over the 1980-2005 period, computer hardware accounted for $25 \%$ of ICT investment in France, against 40\% in the United Kingdom, 28\% in the United States and 45\% in Japan.
} 


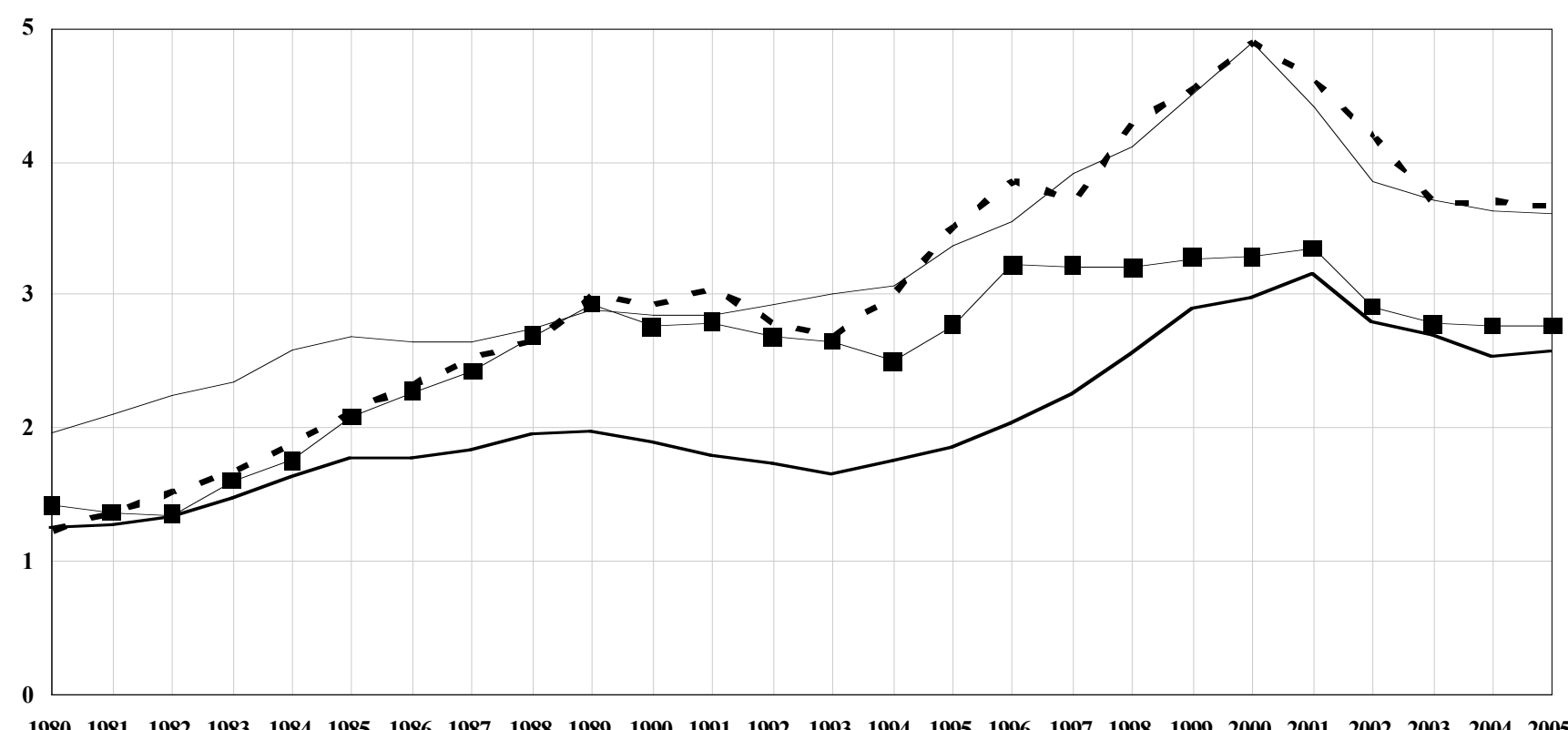

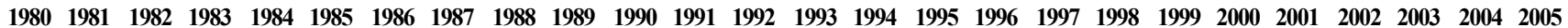

- France —- Japan - - United Kingdom - United States

Fig. (5). ICT investment ratio (in percentage points) in France, the United Kingdom, the United States and Japan 1980-2005. Scope: Economy as a whole. Sources: see Box 1.

Table 9. Average Annual ICT Price Growth (as a \%) in France, the United Kingdom, the United States and Japan- 1980-2005

\begin{tabular}{|c|c|c|c|c|c|}
\hline & $\mathbf{1 9 8 0 - 2 0 0 5}$ & $\mathbf{1 9 8 0 - 1 9 9 0}$ & $\mathbf{1 9 9 0 - 1 9 9 5}$ & $\mathbf{1 9 9 5 - 2 0 0 0}$ & $\mathbf{2 0 0 0 - 2 0 0 5}$ \\
\hline \hline France & -4.0 & -1.5 & -5.8 & -6.7 & -4.5 \\
\hline Japan & -5.7 & -3.5 & -6.6 & -9.5 & -5.3 \\
\hline United Kingdom & -5.2 & -3.5 & -5.9 & -8.2 & -4.8 \\
\hline United States & -4.8 & -3.5 & -5.4 & -4.3 \\
\hline
\end{tabular}

Sources and estimations: See Box 1 and Box 2.

- $\quad$ The contribution of ICT capital to average annual productivity growth (per employee or per hour) ranges, depending on the period, from 0.3 point to 0.7 point in the United States and the United Kingdom, from 0.3 point to 0.6 point in Japan and finally from 0.2 point to 0.3 point in France. The ICT investment ratio is roughly the same in the United Kingdom and the United States (see Fig. 5), and the contribution of ICTs to productivity growth is also the same. This important ICT impact can be attributed to the significantly fast average annual growth rate of the capital stock due to the fast decrease in the global ICT price index (see Table 9). Compared to previous studies, the result that contribution to productivity growth of ICT capital deepening was the same in the United Kingdom and in the United States can be attributed to the improvement in the measure of ICT investment in the United Kingdom. The new figure for ICT investment in the United Kingdom takes better account of the importance of the services sector, and particularly financial services, in the UK economy. In France and
Japan, the investment ratio is low and the annual growth rate of ICT capital per capita is slightly lower than in the United States;

- In all four countries, the contribution of ICT capital is the largest over the 1995-2000 period. It amounts to roughly 0.7 point in the United States and the United Kingdom, 0.6 point in Japan and 0.3 point in France. At the same time, the contribution of other equipment and buildings declined considerably in France, Japan and the United Kingdom compared with the previous period (about 1 point). The faster decline in ICT prices over this period (Table 9) seems to have accelerated the substitution between ICT capital and non-ICT capital;

- Lastly, after 2000, the fall in ICT investment is directly reflected in the contribution of ICT capital to productivity growth. This effect is the less pronounced in France ( -0.1 point and -0.2 to -0.3 point in the other three countries). Except in Japan, this period was also marked by an increase in the contribution of non-ICT capital deepening to 
productivity growth in all countries, particularly in the United States (about 0.4 point).

Cette and Lopez (2008) [39] analyse with more details the ICT diffusion gap among major industrialised countries vis-à-vis the United States during the period 1981-2005. Their results confirm the (positive) impact of the share of the population having completed higher education and the (negative) impact of market rigidities on ICT diffusion. These effects are heightened when ICT diffusion is already substantial. Compared to the United States, the lower ICT diffusion is explained for the United Kingdom by a lack of higher educated employees and for France and Japan by a lack of education and also by higher market rigidities.

On the whole, the results presented here are in keeping with those obtained in the most recent international comparative studies, such as those by Jorgenson and Kuong (2005) [40], the OECD (2003) [41] and Timmer, Ypma and van Ark (2003) [42] or Van Ark and Piatkowski (2004) [43], presented in Table 10. As regards France, they are consistent with our previous assessments (see Cette, Mairesse and Kocoglu, 2005b) [36]. For the United Kingdom, they are not directly comparable with the recent assessments by Oulton and Srinivasan (2005) [44] on the market economy; although their profile is similar, the contribution of ICTs is lower than in our estimates. According to these authors, the contribution of ICT capital deepening accounts for 0.7 point of the average annual increase in hourly labour productivity between 1979 and 1990 and for 1 point over the 1990-2000 period. As regards the United States, our results are, considering the scope difference, very close to those of Jorgenson, Ho and Stiroh (2006) [45], (2008) [46], and Oliner, Sichel and Stiroh (2007) [47] presented in Table 11. As regards Japan, our estimates are close to those of Jorgenson and Kuong (2005) [40] and Jorgenson and Motohashi (2005) [48] for the 1990s but show a higher decrease in the contribution of ICT capital deepening to growth during the period 2000-2006.

As mentioned above, national accountants are faced with a number of methodological problems when assessing ICT investment expenditure and establishing the volume-price breakdown. However, since national accountants have been following the recommendations of the OECD-Eurostat Software Task Force, the measure of investment in software is more homogenous across countries. For example, the share of software in total ICT investment is comparable in the four countries (between $50 \%$ and $60 \%$ ), while the previous data indicated that this share was twice as high in the United States as in France (see Cette, Mairesse and Kocoglu, 2000 [50] and 2002a [33]). Although this international harmonisation has made international comparisons of ICT contributions to productivity growth more robust, progress still needs to be made with regard to the measurement of own account software and the quality effect.

Table 10. Average Annual ICT Contribution to the Growth of GDP or Labour Productivity (In Percentage Points) in France, the United Kingdom, the United States and Japan

\begin{tabular}{|c|c|c|c|c|c|c|c|}
\hline & \multicolumn{3}{|c|}{ Jorgenson and Kuong (2005)* [40] } & \multicolumn{2}{c|}{ OECD (2003)* [41] } & $\begin{array}{c}\text { Van Ark and Piatkowski } \\
(\mathbf{2 0 0 4})^{* *}[\mathbf{4 3}]\end{array}$ & $\begin{array}{c}\text { Van Ark, O'Mahony } \\
\text { and Timmer (2008) [49] }\end{array}$ \\
\cline { 2 - 8 } & $\mathbf{1 9 8 9 - 1 9 9 5}$ & $\mathbf{1 9 9 5 - 2 0 0 0}$ & $\mathbf{2 0 0 0 - 2 0 0 4}$ & $\mathbf{1 9 9 0 - 1 9 9 5}$ & $\mathbf{1 9 9 5 - 2 0 0 1}$ & $\mathbf{1 9 9 5 - 2 0 0 1}$ & $\mathbf{1 9 9 5 - 2 0 0 4}$ \\
\hline \hline France & 0.2 & 0.4 & 0.4 & 0.2 & 0.3 & 0.3 & 0.5 \\
\hline Japan & 0.3 & 0.8 & 0.6 & 0.3 & 0.6 & na & 0.6 \\
\hline United Kingdom & 0.3 & 0.8 & 0.3 & 0.3 & 0.6 & 0.9 & 0.7 \\
\hline United States & 0.5 & 1.0 & 0.6 & 0.5 & 0.9 & 0.8 \\
\hline
\end{tabular}

Results of some international comparisons.

* Contribution to GDP growth, ** Contribution to the growth of the labour productivity per employee.

Scope: Whole economy.

Table 11. Average annual labour productivity growth and contributions (in percentage points) In the United States

\begin{tabular}{|c|c|c|c|c|c|c|c|c|}
\hline & \multicolumn{4}{|c|}{ Oliner Sichel and Stiroh $(2007) *[47]$} & \multicolumn{4}{|c|}{ Jorgenson, Ho and Stiroh $(2008) * *[46]$} \\
\hline Capital intensity per hour & 0.76 & 1.11 & 0.85 & 1.14 & 1.40 & 0.85 & 1.51 & 1.26 \\
\hline Non-ICT capital intensity per hour & 0.30 & 0.02 & 0.24 & 0.70 & 1.19 & 0.45 & 0.49 & 0.69 \\
\hline
\end{tabular}




\section{CONCLUSION}

The results of our study, despite being extremely aggregated and global, are nevertheless rich and difficult to summarise. The most striking findings are the following. The past 120 years have been characterised by very important economic growth and productivity gains in the four countries under review, the remarkable catching-up of the United States by France, the fact that the United Kingdom has reached a par with the United States and France after a long relative decline, and the impressive catching-up of Japan which came to a stop in the 1990s.

At present, total factor productivity is very close in the countries under review except Japan, where it is still significantly lower. However, hourly labour productivity is slightly higher in France than in the United States, significantly lower in the United Kingdom, and even lower in Japan. Furthermore, productivity per employee is slightly lower in France than in the United States, much lower in the United Kingdom and even lower in Japan. These performances reflect the more or less contrasting developments during the various periods of the analysis, associated with varying contributions of capital deepening and the downward trend in working hours.

Between 1890 and 2006, the faster drop in working time accounts for roughly $25 \%$ of the differential in the growth of productivity per employee between France and the United States, and just about 5\% of that between the United Kingdom and the United States. Similarly, over this same period, the lower contribution of capital deepening explains $15 \%$ of the differential in the growth of productivity per employee between France and the United States and almost $25 \%$ of that between the United Kingdom and the United States. The other growth factors included in the concept of total factor productivity account for $100 \%$ of France's catching-up with US labour productivity and for $40 \%$ of the decline in British labour productivity compared with the United States. These other growth factors (the decline in working hours and capital deepening being equal) would thus account for the almost three-fold increase in French labour productivity compared with the United Kingdom, i.e. an average annual growth differential over 116 years of $1.0 \%$.

It appears that the productivity catching-up process differs strongly among countries and periods. The three important questions are then: (i) why do some countries (and not others) benefit at certain periods (and not others) from a productivity catching-up of the highest country level? (ii) What are the determinants of the speed of this catching-up process when it happens? (iii) Why is this catching-up process achieved for some countries but ends before being achieved for others? Important recent literature (see Cette and Lopez, 2008 [39] for a survey of the literature) suggests that these differences can mainly be explained by the education level of the working age population and by institutional aspects, as rigidities in labour, product and financial markets. However, the respective contribution of each of these different factors has not been precisely quantified yet.

\section{REFERENCES}

[1] Maddison A. L'économie mondiale: Statistiques historiques. Paris: OECD 2003 ; pp. 69-13.

[2] Maury T, Pluyaud B. Les ruptures de tendance de la productivité par employé de quelques grands pays industrialisés. Banque de France Bulletin 2004; 121: 69-113.

[3] Cahn C, Saint-Guilhem A. Potential output growth in several industrialised countries: A comparison. Banque de Franee: Mimeo 2006.

[4] Kocoglu Y. La productivité du capital productif fixe sur longue période: Une analyse empirique sur la France. Histoire Économie et Société 2001; $1: 65-85$.

[5] Villa P. Un siècle de données macroéconomiques. Insee Résultats, Série Economie générale 1994; pp. 86-7.

[6] Maddison A. L'économie mondiale : une perspective millénaire. Paris: OECD 2001.

[7] Feinstein CH. Statistical tables of national income, expenditure and output of the United Kingdom. Cambridge: Cambridge University Press 1976; pp. 1855-1965.

[8] Mitchell B. The Americas, 1750-1993. International historical statistics,. $4^{\text {th }}$ ed. New York: Stockton Press 1998.

[9] Maddison A. Standardised estimates of fixed capital stock: a six country comparison. Innovazione e Materie Prime. Essays on Innovation, Natural Resources and International Economy. Mimeo 1993.

[10] Lévy-Leboyer M. Capital investment and economic growth in France, 1820-1913. Chapter V. The Cambridge History of Europe. Cambridge: Cambridge University Press 1978;: pp. 231-95.

[11] Bank of Japan. Hundred Year Statistics of the Japanese economy, Statistics Department. Mimeo 1966; p. 27.

[12] Colecchia A, Schreyer P. ICT Investment and Economic Growth in the 1990s: Is the United States a Unique Case? A Comparative Study of 9 OECD Countries 2001, DSTI/DOC(2001)7.

[13] Maddison A. Contours of the world economy, I-2030 AD. Oxford: Oxford University Press 2007.

[14] Solow R. A contribution to the theory of growth. Q J Econ 1956; 70 : 65-94.

[15] Solow R. Technical change and aggregate production function. Rev Econ Stat 1957; 39: 312-20.

[16] Griliches Z. The discovery of the Residual: a historical note. J Econ Lit 1996; 34: 1324-30.

[17] Cette G. Diagnostic macroéconomique et lecture historique. Artus P et Cette G Productivité et croissance. Rapport du CAE 2004; Vol. 48.

[18] Cette G. Productivité et croissance en Europe et aux Etats-Unis. La découverte Collection Repères 2007.

[19] Maddison A. Dynamic forces in capitalist development. Oxford: Oxford University Press 1994.

[20] Bourlès R, Cette G. A comparison of structural productivity levels in the major industrialised countries. OECD Econ Stud 2005; 41: 75107.

[21] Bourlès R, Cette G. Trends in 'structural' productivity levels in the major industrialized countries. Econ Lett 2007; 95 : 151-6.

[22] Gordon R. Deux siècles de croissance économique: l'Europe à la poursuite des Etats-Unis. Revue de l'OFCE 2003; 84: 9-46.

[23] Van Ark B, Frankema E, Duteweerd H. productivity and employment growth: an empirical review of long and medium run evidence. research memorandum GD-71. Groningen Growth and Development Centre 2004.

[24] Dubois P. Rupture de croissance et progrès technique. Economie et Statistique 1985; 181: 3-31.

[25] Carré JJ, Dubois P, Malinvaud E. La croissance française. Paris: France: un essai d'analyse économique causale de l'après guerre. Seuil 1972.

[26] Crafts N. Steam as a general purpose technology: A growth accounting perspective. Econ J 2004; 114: 338-51.

[27] Crafts N. Fifty years of economic growth in Western Europe. World Econ 2004; 5(2): 45-58.

[28] Crafts N. The world economy in the 1990s: a long run perspective. London: London School of Economics, Department of Economic History Working Paper 8704, 2004.

[29] Ferguson RW, Washer WL. Distinguished lecture on economics in government: Lesson from past productivity booms. J Econ Perspect 2004; 18: 3-28.

[30] Gordon R. US economic growth since 1970: One big wave? Am Econ Rev 1999; 89(2): 123-8. 
[31] Card D, Freeman RB. What have two decades of british economic reform delivered? NBER Working Paper 8801, 2002.

[32] Gordon R. Pourquoi, pendant que la locomotive de le productivité se mettait en branle aux États-Unis, l'Europe est elle-restée en gare ? L'Actualité économique, Revue d'analyse économique 2005; 81: 1-2.

[33] Cette G, Mairesse J, Kocoglu Y. Croissance économique et diffusion des TIC: le cas de la France sur longue période (19802000). Revue Française d'Économie 2002; 16: 3.

[34] Cette G, Mairesse J, Kocoglu Y. Diffusion of ICTs and growth of the French economy over the long-term, 1980-2000. International Productivity Monitor 2002; 4: 27-38.

[35] Cette G, Mairesse J, Kocoglu Y. Effets de la diffusion des TIC sur la croissance potentielle et observée. L'Actualité économique, Revue d'analyse économique 2005; 81: 1-2.

[36] Cette G, Mairesse J, Kocoglu Y. Un siècle de productivité en France. Banque de France Bull 2005; 139 : 21-9.

[37] Cette G, Mairesse J, Kocoglu Y. La mesure de l'investissement en technologies de l'information et de la communication: quelques considérations méthodologiques. Économie et Statistique 2000; 9(10): 339-40.

[38] Chesson A, Chamberlin G. Survey-based measures of software investment in the UK. Econ Trends 2006; 627: 61-72.

[39] Cette G, Lopez J. What explains the ICT diffusion gap between the major industrialized countries: an empirical analysis? International Productivity Monitor 2008; (17): 28-39.

[40] Jorgenson DW, Kuong V. Information technology and the world economy. Scand J Econ 2005; 107(4): 65-114.
[41] OECD, ICT and economic growth: Evidence from OECD countries. Industries and Firms, Paris, OECD 2003.

[42] Timmer MP, Ypma G, Van Ark B. IT in the European Union: Driving productivity divergence? Research Memorandum GD-67. Groningen Growth and Development Centre 2003.

[43] Van Ark B, Piatkowski M. Productivity, innovation and ICT in old and new Europe. Research memorendum GD-69. Groningen Growth and Development Centre 2004.

[44] Oulton N, Srinivasan S. Productivity growth in UK industries, 1970-2000: structural change and the role of ICT London. Bank of England Working Paper 259, 2005.

[45] Jorgenson DW, Ho MS, Stiroh KJ. Potential growth of the US economy: Will the productivity resurgence continue? Bus Econ 2006.

[46] Jorgenson DW, Ho MS, Stiroh KJ. A retrospective look at the U.S. Productivity growth resurgence. J Econ Perspect 2008; 22(1): 3-24.

[47] Oliner S, Sichel D, Stiroh KJ. Explaining a productive decade. Brookings Pap Econ Act 2007; 1: 81-137.

[48] Jorgenson DW, Motohashi K. Information technology and the Japanese economy. J Jpn Int Econ 2005; 19(4): 460-81.

[49] Van Ark B, O’Mahony M, Timmer M. The productivity gap between Europe and the United States: Trends and causes. J Econ Perspect 2008; 22(1): 25-44.

[50] Mairesse J, Cette G, Kocoglu Y. Les Technologies de l'information et de la communication en France: Diffusion et contribution à la croissance. Economie et Statistique 2000; 9/10: 339-40.

Received: February 9, 2009

Revised: July 10, 2009

Accepted: July 10, 2009

(C) Cette et al.; Licensee Bentham Open.

This is an open access article licensed under the terms of the Creative Commons Attribution Non-Commercial License (http://creativecommons.org/licenses/by-nc/ 3.0/) which permits unrestricted, non-commercial use, distribution and reproduction in any medium, provided the work is properly cited. 